\title{
Recurrent Transformed Follicular Lymphoma to Diffuse Large B-Cell Lymphoma
}

National Cancer Institute

\section{Source}

National Cancer Institute. Recurrent Transformed Follicular Lymphoma to Diffuse Large B-Cell Lymphoma. NCI Thesaurus. Code C160232.

The reemergence of transformed follicular lymphoma to diffuse large B-cell lymphoma after a period of remission. 